\title{
Report \\ Weed Control as a Rationale for Restoration: The Example of Tallgrass Prairie
}

\author{
$\underline{\text { Dana M. Blumenthal, Nicholas R. Jordan, and Elizabeth L. Svenson }}$
}

\begin{abstract}
The potential weed control benefits of ecological restoration are rarely cited and largely unstudied. Nevertheless, the nature of many restoration target communities, i.e., diverse, late-successional communities, suggests that restoration may control weeds and that the invasibility of plant communities may decrease with both diversity and successional age. Given the high cost of weed control in nonagricultural land, weed control benefits could be a strong incentive for restoration efforts. We examined the cumulative effects of restoration on weed populations $7 \mathrm{yr}$ after tallgrass prairie restoration on a Minnesota sand plain. The numbers and biomass of volunteer weeds were compared among randomized plots with (1) no restoration, (2) prairie seed addition, and (3) site preparation plus prairie seed addition. After $7 \mathrm{yr}$, comparison with unrestored sites showed that site preparation plus prairie seed addition had reduced weed biomass by $94 \%$, total weed stem number by $76 \%$, and the stem numbers of four individual weed species. Prairie seed addition alone had no significant effect on weed biomass but reduced weed stem number by $45 \%$. Restoration also reduced available light, which is consistent with the hypothesis that restoration may limit weed invasion by decreasing resource availability.
\end{abstract}

\section{INTRODUCTION}

Commonly cited benefits of restoring native plant communities include increases in native biological diversity; improved control of flows of water, sediment, and nutrients; detoxification of polluted areas; and increases in recreational opportunities (Edwards and Abivardi 1997). However, restoration may also be a useful method of weed control (Cramer 1991, Berger 1993, Jacobs and Sheley 1999). Currently, weeds are controlled in many areas not actively used for crop production, such as roadsides, field margins, and old fields, to keep weed populations from invading nearby fields and to slow the spread of weed populations across the landscape. Given the high cost of such weed control (Westbrooks 1998), the potential weed control benefits of restoration could provide a powerful incentive for restoring native plant communities.

Restoration could be expected to control weeds if diverse, late-successional native plant communities, the target of many restoration efforts, were less invasible than the types of vegetation planted in noncropland, often fast-growing, introduced species. In fact, patterns of community invasibility suggest that both diverse plant communities and late-successional plant communities may be relatively resistant to invasion. Diverse plant communities may use resources more completely, leaving fewer resources available for potential invaders (Case 1990, Jacobs and Sheley 1999). Recent experimental studies have found that increasing species diversity reduces community invasibility (Tilman 1997, Naeem et al. 2000). Latesuccessional plant communities may contain more competitive species and lower levels of available resources than do early-successional plant communities (Vitousek and Walker 1987, Bazzaz 1996). Observational studies have found fewer invaders in late- than in early-successional plant communities (Rejmanek 1989). Finally, native plant species should compete well under local climatic and edaphic conditions. Because early-successional species such as agricultural weeds are adapted to high levels of available resources (Baker 1965, Chapin 1980), they may be particularly unlikely to invade resource-poor plant communities. Therefore, diverse, latesuccessional native plant communities may exclude many common weed species.

Some anecdotal evidence suggests that such plant communities can control weeds (e.g., Cramer 1991). However, the opposite situation, i.e., weeds inhibiting the restoration of native species, is more often 
mentioned (Berger 1993, D'Antonio and Meyerson 2002). Weed invasions of restored plant communities may be transient, the result of disturbance associated with restoration, or persistent if environmental conditions have changed or weed species are well adapted to undisturbed ecosystems (Berger 1993). Despite the prevalence of weed problems in restoration, the long-term effects of restoration on weeds are not well known. In particular, few studies have compared weed populations among restored and unrestored plant communities. In a study of California roadsides restored to native perennial grasses, cover by undesirable species was not found to be significantly lower in native than non-native grass mixtures (Bugg et al. 1997). Additional empirical studies comparing weed invasion among restored plant communities and typical roadside or other noncropland vegetation are needed to determine the weed control value of restoration.

The objective of this study was to test whether restored tallgrass prairie limited weed invasion when compared with cool-season grass communities similar to those planted in roadsides, lawns, and field margins in the United States. This study provides a unique experimental approach to this question, examining weed abundance and biomass in randomized plots of both restored prairie and unrestored cool-season grass plant communities. To construct hypotheses about which resources might mediate the effects of restored prairie on weed populations, we also measured the availability of water, nitrogen, and light.

\section{METHODS}

\section{Experimental design and study site}

Weed abundance and biomass and light, water, and nitrogen availability were compared among three treatments: no restoration, prairie seed addition only (seed-only restoration), and prairie seed addition plus site preparation (intensive restoration). Restoration treatments were established in 1993 (Svenson 1995) in an old field at Cedar Creek Natural History Area (CCNHA), Bethel, Minnesota. The field was last cultivated in 1965 and has an excessively drained finesand soil (Grigal et al. 1974). To our knowledge, the site did not burn between field abandonment and the start of this experiment. The dominant species in the old field (Poa pratensis) and the restored prairie (Schizachyrium scoparium) are common at CCNHA in mid- and late-successional old fields, respectively (Tilman 1988). This study site provided an opportunity to study the long-term effects of restoration on weeds in a randomized experiment. However, the applicability of the results to other areas may be limited by the small scale of the experiment and the low levels of available soil nitrogen at the site, which are characteristic of the CCNHA but not of soils throughout the tallgrass prairie region as a whole.

Five replicates of the three prairie restoration treatments were applied to $6 \times 6 \mathrm{~m}$ plots in a randomized complete-block design (Svenson 1995). Data were collected within the central $5 \times 5 \mathrm{~m}$ of each plot to avoid edge effects from adjacent plots. Intensive restoration plots were treated with glyphosate $\left(110 \mathrm{ml} / \mathrm{m}^{2}\right)$ in the form of maximumstrength Roundup ${ }^{\circledR}$ on 15 May 1993, burned on 15 June 1993, and rototilled to a depth of $5-8 \mathrm{~cm}$, raked, and packed on 17-18 June 1993. Seeds of five prairie grasses and 13 prairie forbs (Table 1) were broadcast by hand in both intensive restoration and seed-only restoration plots on 17-18 June 1993. No treatment was applied to unrestored plots in 1993. Restored plots received 100 seeds $/ \mathrm{m}^{2}$ of all species except Bouteloua curtipendula, Elymus canadensis, Helianthus pauciflorus, and Asclepias tuberosa, which were seeded at 50 seeds $/ \mathrm{m}^{2}$ because of limited seed availability. All treatments were burned in the fall of 1995 and again in the fall of 1998.

\section{Species classification}

Within the context of weed control in the tallgrass prairie region, the relevant definition of "weed" is any undesirable species, that is, a species toward which control efforts are being directed. We classified species as weeds if they were present in common weed keys, listed as noxious weeds in Minnesota, or exotic to the United States (Table 1). Two dominant extant species that are classified as weeds in some contexts, Poa pratensis and Bromus inermis, were not classified as weeds in this study because they are more often considered to be desirable species. The presence of these species and their classification as desirable species allows us to compare the weed control value of restored prairie to the weed control value of species commonly planted to control weeds. One of the seeded prairie species, Monarda fistulosa, is also included in a weed key but was not classified as a weed because it is commonly considered to be a desirable species in tallgrass prairie restoration. 
Table 1. Classification of extant and added species. Possible subclasses in the third column are monocot (M) and dicot (D). Cycles represented in the fifth column are annual (A), biennial (B), and perennial (P). Native (N) and exotic (E) are the origins in the sixth column. The "yes" and "no" answers in the seventh and eighth columns indicate whether or not the species is regarded as a noxious weed in Minnesota and whether or not it is listed in weed keys, respectively.

\begin{tabular}{lcccccc}
\hline & \multicolumn{2}{c}{ Weeds (extant undesirable species) } & & & \\
\cline { 2 - 5 } Species & Common name & Subclass & Cycle & Origin $^{1}$ & Weed $^{2}$ & Keys $^{3}$ \\
\hline Achilles millefolium & common yarrow & D & P & E & no & yes \\
Ambrosia artemisiifolia & common ragweed & D & A & N & yes & yes \\
Ambrosia psilostachya & western ragweed & D & P & N & no & yes \\
Artemisia ludoviciana & white sage & D & P & N & no & yes \\
Berteroa incana & hoary alyssum & D & B/P & E & yes & yes \\
Conyza canadensis & horseweed & D & A & N & no & yes \\
Elytrigia repens & quackgrass & M & P & E & yes & yes \\
Euphorbia maculata & milk purslane & D & A & N & no & yes \\
Polygonum convolvulus & wild buckwheat & D & A & E & yes & yes \\
Potentilla argentea & silvery cinquefoil & D & P & E & no & no \\
Rumex acetosella & red sorrel & D & P & E & no & yes \\
Setaria glauca & yellow foxtail & M & A & E & no & yes \\
\hline
\end{tabular}

Extant desirable species

\begin{tabular}{lcccccc}
\cline { 2 - 5 } Species & Common name & Subclass & Cycle & Origin & Weed & Keys \\
\hline Bromus inermis & smooth brome & $\mathrm{M}$ & $\mathrm{P}$ & $\mathrm{E}$ & no & yes \\
Panicum oligosanthes & Scribner's panic grass & $\mathrm{M}$ & $\mathrm{P}$ & $\mathrm{N}$ & no & no \\
Poa pratensis & Kentucky bluegrass & $\mathrm{M}$ & $\mathrm{P}$ & unknown & no & yes \\
\hline
\end{tabular}

Seeded prairie species

\begin{tabular}{lcccccc}
\cline { 2 - 5 } Species & Common name & Subclass & Cycle & Origin & Weed & Keys \\
\hline Andropogon gerardii & big bluestem & $\mathrm{M}$ & $\mathrm{P}$ & $\mathrm{N}$ & no & no \\
Asclepias tuberosa & butterfly weed & $\mathrm{D}$ & $\mathrm{P}$ & $\mathrm{N}$ & no & no
\end{tabular}




\begin{tabular}{|c|c|c|c|c|c|c|}
\hline Aster oolentangiensis & sky blue aster & $\mathrm{D}$ & $P$ & $\mathrm{~N}$ & no & no \\
\hline Bouteloua curtipendula & sideoats gramma & $\mathrm{M}$ & $\mathrm{P}$ & $\mathrm{N}$ & no & no \\
\hline Dalea purpurea & purple prairie clover & $\mathrm{D}$ & $\mathrm{P}$ & $\mathrm{N}$ & no & no \\
\hline Dalea candida & white prairie clover & $\mathrm{D}$ & $\mathrm{P}$ & $\mathrm{N}$ & no & no \\
\hline Elymus canadensis & Canada wild rye & M & $\mathrm{P}$ & $\mathrm{N}$ & no & no \\
\hline Helianthus pauciflorus & stiff sunflower & $\mathrm{D}$ & $\mathrm{P}$ & $\mathrm{N}$ & no & no \\
\hline Lespedeza capitata & bush clover & $\mathrm{D}$ & $\mathrm{P}$ & $\mathrm{N}$ & no & no \\
\hline Liatris aspera & rough blazing star & $\mathrm{D}$ & $\mathrm{P}$ & $\mathrm{N}$ & no & no \\
\hline Monarda fistulosa & wild bergamot & $\mathrm{D}$ & $\mathrm{P}$ & $\mathrm{N}$ & no & yes \\
\hline Penstemon gracilis & slender beard-tongue & $\mathrm{D}$ & $\mathrm{P}$ & $\mathrm{N}$ & no & no \\
\hline Penstemon grandiflorus & $\begin{array}{l}\text { large-flowered } \\
\text { beard-tongue }\end{array}$ & $\mathrm{D}$ & $\mathrm{P}$ & $\mathrm{N}$ & no & no \\
\hline Rudbeckia hirta & Black-eyed Susan & $\mathrm{D}$ & $\mathrm{B} / \mathrm{P}$ & $\mathrm{N}$ & no & no \\
\hline Schizachyrium scoparium & little bluestem & M & $\mathrm{P}$ & $\mathrm{N}$ & no & no \\
\hline Solidago rigida & stiff goldenrod & $\mathrm{D}$ & $\mathrm{P}$ & $\mathrm{N}$ & no & no \\
\hline Solidago speciosa & showy goldenrod & $\mathrm{D}$ & $\mathrm{P}$ & $\mathrm{N}$ & no & no \\
\hline Sorghastrum nutans & Indian grass & $\mathrm{M}$ & $\mathrm{P}$ & $\mathrm{N}$ & no & no \\
\hline
\end{tabular}

${ }^{1}$ Gleason and Cronquist 1981

${ }^{2}$ Durgan 1998

${ }^{3}$ USDA 1971, Stubbendieck et al. 1994

\section{Measurement of plant mass, number, and cover}

The effects of restoration on weeds were tested by comparing weed biomass and stem numbers among treatments at a single point in time $7 \mathrm{yr}$ after prairie restoration. Percent weed cover, estimated in the first two years after prairie restoration, was included to separate the effects of site preparation from those of prairie establishment for the intensive restoration treatment. Biomass, number, and cover of weed species were each measured in separate subplots. Subplots were placed in fixed locations within whole plots; where necessary, subplot location was adjusted to avoid soil disturbance by Geomys bursarius (pocket gopher). The biomass of all weed and prairie species was collected from $1 \times 1 \mathrm{~m}$ subplots in September 2000. Plants were clipped within $1 \mathrm{~cm}$ of the soil surface, dried at $60^{\circ} \mathrm{C}$, and weighed. To maximize the possibility of detecting species-specific responses to restoration, stem counts were conducted within a larger area. Stems of all weed species were counted, and cover of prairie species was estimated in four $1 \mathrm{x} 1$ $\mathrm{m}$ subplots within each whole plot in early August 2000. Cover of all weed species was estimated in $1 \mathrm{x}$ $0.5 \mathrm{~m}$ subplots in September 1993 and August 1994 
(Svenson 1995). Cover estimates were scaled to obtain a total cover value for each plot, including bare ground, of $100 \%$.

\section{Measurement of soil water and nitrogen}

Soil water content, available $\mathrm{NH}_{4}$, and available $\mathrm{NO}_{3}$ were sampled in July 2000 . Five soil cores $20 \mathrm{~cm}$ long and $2 \mathrm{~cm}$ in diameter were pooled from each biomassharvest subplot. Soil was stored on ice $(<2 \mathrm{~h})$ prior to $\mathrm{N}$ extraction with $0.01 \mathrm{M} \mathrm{KCl}$. Concentrations of ammonium and $\mathrm{NO}_{3}$ were measured using a continuous-flow RFA 300 Alpkem ${ }^{\circledR}$ autoanalyzer and method A303-S170-04. Soil not used for N extraction was weighed, dried at $105^{\circ} \mathrm{C}$, and reweighed to determine its water content.

\section{Measurement of light penetration}

Light penetration was measured in biomass-harvest subplots in late June and early September 2000. Percent light penetration was measured using a LICOR Quantum line sensor and, for above-canopy measurements only, a LI-COR Quantum point sensor. All measurements were taken within $2 \mathrm{~h}$ of solar noon on clear or partly cloudy days. Percent light penetration was measured as 100 times the ratio of below- to above-canopy light intensity.

\section{Data analysis}

The data were analyzed using SAS statistical software (SAS Institute 1990). All analyses involved a two-way ANOVA, with three levels of restoration and five blocks. Transformations were used to meet ANOVA assumptions regarding homoscedasticity and normality. Most response variables were logtransformed prior to analysis (Tables 2 and 3). Pairwise comparisons of restoration treatments were conducted using Tukey's HSD method. Significant outliers were identified using outlier t-statistics (Cook and Weisberg 1999). One outlier was identified and removed from analyses of weed stem number. This seed-only restoration plot had very low cover of prairie species $(22 \%)$ relative to the mean in other seed-only restoration plots $(55 \%)$ and a very high weed stem number; it was also a significant outlier in the analysis of total weed stem number (outlier tstatistic $=3.16, P=0.0046)$. Uneven terrain and gopher mounds within the plot suggested that recent gopher activity may have led to this unusually low cover of prairie species and high abundance of weeds.

\section{RESULTS}

\section{Weed biomass}

Restoration significantly decreased total weed biomass compared to no restoration (Table 2, Fig. 1). Weed biomass in intensively restored plots was $6 \%$ that of unrestored plots. Seed-only restored plots did not differ significantly in biomass from unrestored plots. The weeds observed in biomass-collection subplots included, in order of decreasing total biomass, Ambrosia psilostachya, Elytrigia repens, Conyza canadensis, Rumex acetosella, Ambrosia artemisiifolia, Euphorbia maculata, and Potentilla argentea. Berteroa incana and Setaria glauca were also present in biomass-collection subplots, but were not included in total biomass because they could not be separated from individuals of these species added in a separate experiment (D. M. Blumenthal, N. R. Jordan, and E. L. Svenson, unpublished manuscript). Poa pratensis and Bromus inermis were not classified as weeds despite the fact that they are exotic, because they represent the vegetation type to which restored prairie was being compared.

Fig. 1. Mean weed biomass 7 yr after restoration. Means are backtransformed from log-transformed data. Bars with different letters are significantly different based on Tukey HSD tests $(P<0.05)$.

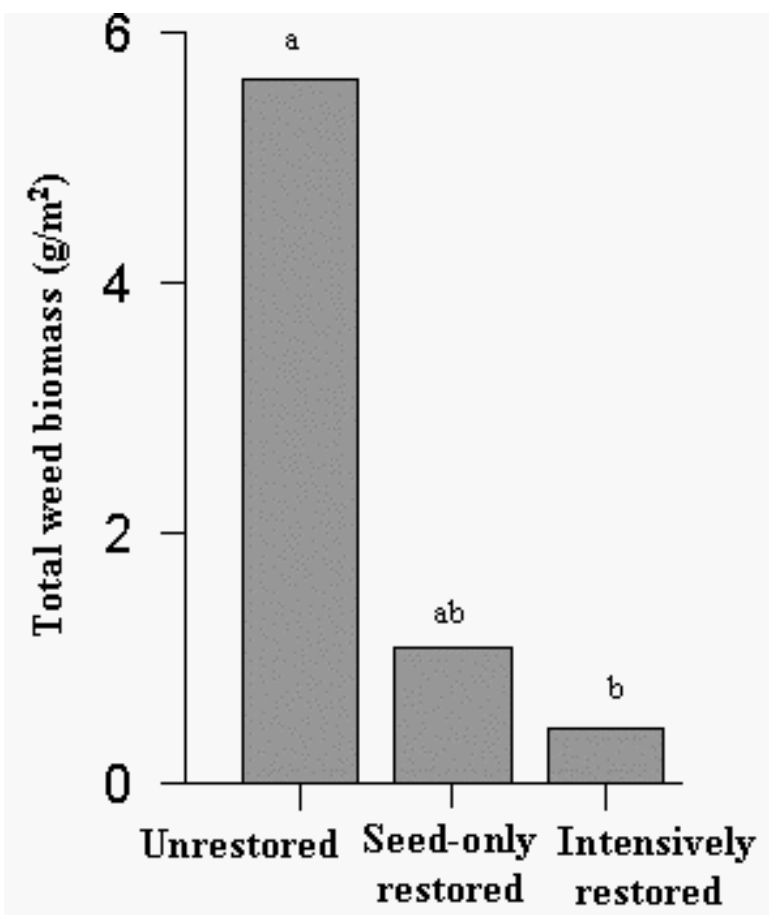


Table 2. ANOVA results for the effect of restoration on weeds, other vegetation, and available resources. Degrees of freedom for block, restoration and error were, 4,2, and 8, respectively. Error degrees of freedom were 7 in analyses of total weed stem number and prairie cover in stem-count subplots.

\begin{tabular}{lccc}
\hline & \multicolumn{2}{c}{ Weeds } & \\
\cline { 2 - 4 } Response variable & Transformation & F statistic & p-value \\
\hline Total weed biomass & $\log$ & 7.06 & 0.017 \\
Total weed biomass & $\log$ & 7.06 & 0.017 \\
Total weed stem number & $\log$ & 16.36 & 0.0023 \\
Total weed cover 1993 & $\log$ & 6.09 & 0.018 \\
\hline
\end{tabular}

Vegetation biomass/richness in biomass subplots

\begin{tabular}{lccc} 
Response variable & Transformation & F statistic & p-value \\
\cline { 2 - 4 } Total biomass & none & 4.86 & 0.031 \\
Prairie grasses & none & 5.52 & 0.031 \\
Prairie forbs & none & 0.64 & 0.55 \\
Extant grasses & none & 4.46 & 0.050 \\
Extant forbs & log & 11.30 & 0.0047 \\
Species richness & none & 20.20 & 0.0007 \\
\end{tabular}

Prairie cover in stem-count subplots

\begin{tabular}{lccc} 
Response variable & Transformation & F statistic & p-value \\
\hline Cover of prairie species & none & 134.71 & $<0.0001$ \\
& & & \\
\hline
\end{tabular}

Resources

\begin{tabular}{lccc}
\cline { 2 - 4 } Response variable & Transformation & F statistic & p-value \\
\hline Light penetration & none & 19.65 & 0.0008 \\
$\mathrm{NO}_{3}$ & none & 2.19 & 0.17
\end{tabular}


Table 3. Effects of restoration on stem numbers of individual weed species. Degrees of freedom for block, restoration, and error were, 4, 2, and 7, respectively.

\section{$\log _{10}$ biomass $\left(\mathrm{g} / \mathrm{m}^{2}\right) \pm$ standard error}

\begin{tabular}{|c|c|c|c|c|c|c|c|c|}
\hline \multirow{2}{*}{$\begin{array}{l}\text { Species } \\
\text { Ambrosia } \\
\text { artemisiifolia }\end{array}$} & \multirow{2}{*}{$\begin{array}{c}\text { F statistic } \\
1.87\end{array}$} & \multirow{2}{*}{$\begin{array}{c}\text { p-value } \\
0.22\end{array}$} & \multicolumn{2}{|c|}{ Unrestored } & \multicolumn{2}{|c|}{ Seed-only restored } & \multicolumn{2}{|c|}{ Intensively restored } \\
\hline & & & 0.45 & \pm 0.15 & 0.28 & \pm 0.11 & 0.42 & \pm 0.12 \\
\hline $\begin{array}{l}\text { Ambrosia } \\
\text { psilostachya }\end{array}$ & 4.47 & 0.056 & 1.18 & \pm 0.41 & 0.67 & \pm 0.33 & 0.43 & \pm 0.14 \\
\hline $\begin{array}{l}\text { Artemisia } \\
\text { ludoviciana }\end{array}$ & 0.88 & 0.45 & 0.21 & \pm 0.21 & 0.00 & \pm 0.00 & 0.035 & \pm 0.035 \\
\hline Berteroa incana & 6.99 & 0.021 & 0.57 & \pm 0.19 & 0.24 & \pm 0.38 & 0.34 & \pm 0.21 \\
\hline Conyza canadensis & 1.35 & 0.32 & 0.80 & \pm 0.10 & 1.15 & \pm 0.090 & 0.89 & \pm 0.18 \\
\hline Elytrigia repens & 19.1 & 0.0015 & 1.09 & \pm 0.16 & 0.69 & \pm 0.098 & 0.035 & \pm 0.035 \\
\hline Euphorbia maculata & 6.7 & 0.02 & 0.98 & \pm 0.35 & 0.20 & \pm 0.17 & 0.035 & \pm 0.035 \\
\hline $\begin{array}{l}\text { Polygonum } \\
\text { convolvulus }\end{array}$ & 0.14 & 0.87 & 0.068 & \pm 0.048 & 0.061 & \pm 0.061 & 0.074 & \pm 0.033 \\
\hline Rumex acetosella & 1.41 & 0.3 & 0.80 & \pm 0.34 & 0.39 & \pm 0.22 & 0.80 & \pm 0.31 \\
\hline Setaria glauca & 10.06 & 0.0087 & 1.02 & \pm 0.27 & 0.20 & \pm 0.17 & 0.00 & \pm 0.00 \\
\hline
\end{tabular}

\section{Weed stem numbers}

Seed-only and intensive restoration reduced total weed stem numbers by 67 and $76 \%$, respectively (Fig. 2). Restoration also significantly reduced the stem numbers for four individual weed species: $B$. incana, E. repens, $E$. maculata, and S. glauca (Table 3). Numbers of stems reflect the abundance of nonclonal species but may reflect the abundance or size of clonal species. Nonclonal weeds observed in stem-count subplots included Achillea millefolium, A. artemisiifolia, B. incana, C. canadensis, E. maculata, Polygonum convolvulus, and S. glauca. Clonal weeds included A. psilostachya, Artemisia ludoviciana, E. repens, and $R$. acetosella.

\section{Weed cover shortly after restoration}

In contrast to weed mass and stem number $7 \mathrm{yr}$ after restoration, percent weed cover in the first two years of the experiment was significantly higher in intensively restored plots than in either unrestored or seed-only restored plots (Fig. 3, Table 2). Total weed cover included all species observed in either stemcount subplots or biomass-harvest subplots, except for A. millefolium and A. ludoviciana, which were not observed in 1993 or 1994. 
Fig. 2. Mean weed stem number $7 \mathrm{yr}$ after restoration. Means are backtransformed from log-transformed data. Bars with different letters are significantly different based on Tukey HSD tests $(P<0.05)$.

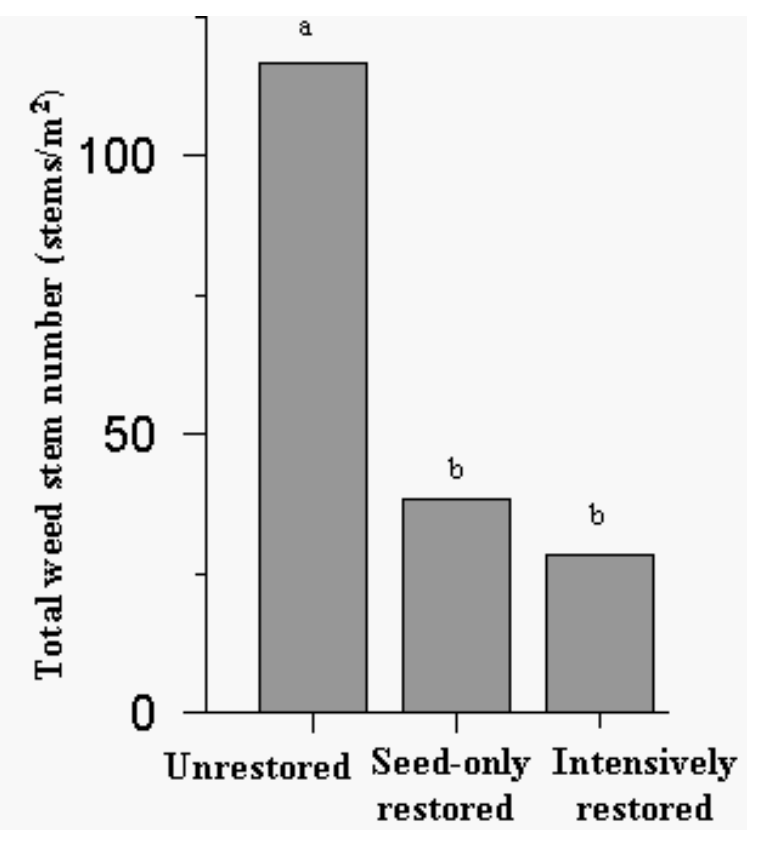

\section{Prairie and nonprairie species in biomass- harvest subplots}

Both seed-only and intensively restored plots had significantly higher total aboveground biomass than did unrestored plots (Table 2, Fig. 4). The higher total aboveground biomass in restored treatments was due mainly to the successful establishment and high biomass production of prairie grasses. Three prairie grasses, Andropogn gerardii, Shizachyrium scoparium, and Sorghastrum nutans, made up the majority of aboveground plant biomass in both seed-only and intensive restoration treatments. Because prairie species had begun to invade unrestored plots, these plots also contained considerable biomass of prairie species. Prairie grass biomass, however, increased significantly with restoration. The biomass of prairie forbs, including Datura candida, Dalea purpurea, Lespedeza capitata, Monarda fistulosa, Penstemon gracilis, P. grandiflorus, Rudbeckia hirta, Solidago rigida, and S. speciosa, was not significantly affected by restoration. The biomass of both extant grasses and extant forbs decreased significantly with restoration. Extant grass biomass consisted primarily of $P$. pratensis but also included $B$. inermis, E. repens, and $P$. oligosanthes. $P$. pratensis and $B$. inermis accounted for $97 \%$ of extant grass biomass.
Extant forb biomass consisted entirely of weed species and included all of the forb weed species observed in biomass-harvest plots. The number of species in biomass subplots also increased significantly with prairie restoration (Table 2), from $8 / \mathrm{m}^{2}$ in unrestored plots to $9.6 / \mathrm{m}^{2}$ in seed-only restored plots and $12.6 / \mathrm{m}^{2}$ in intensively restored plots.

Fig. 3. Mean percent weed cover three and 14 months after restoration. Means are backtransformed from logtransformed data. Bars with different letters are significantly different based on Tukey HSD tests $(P<0.05)$.

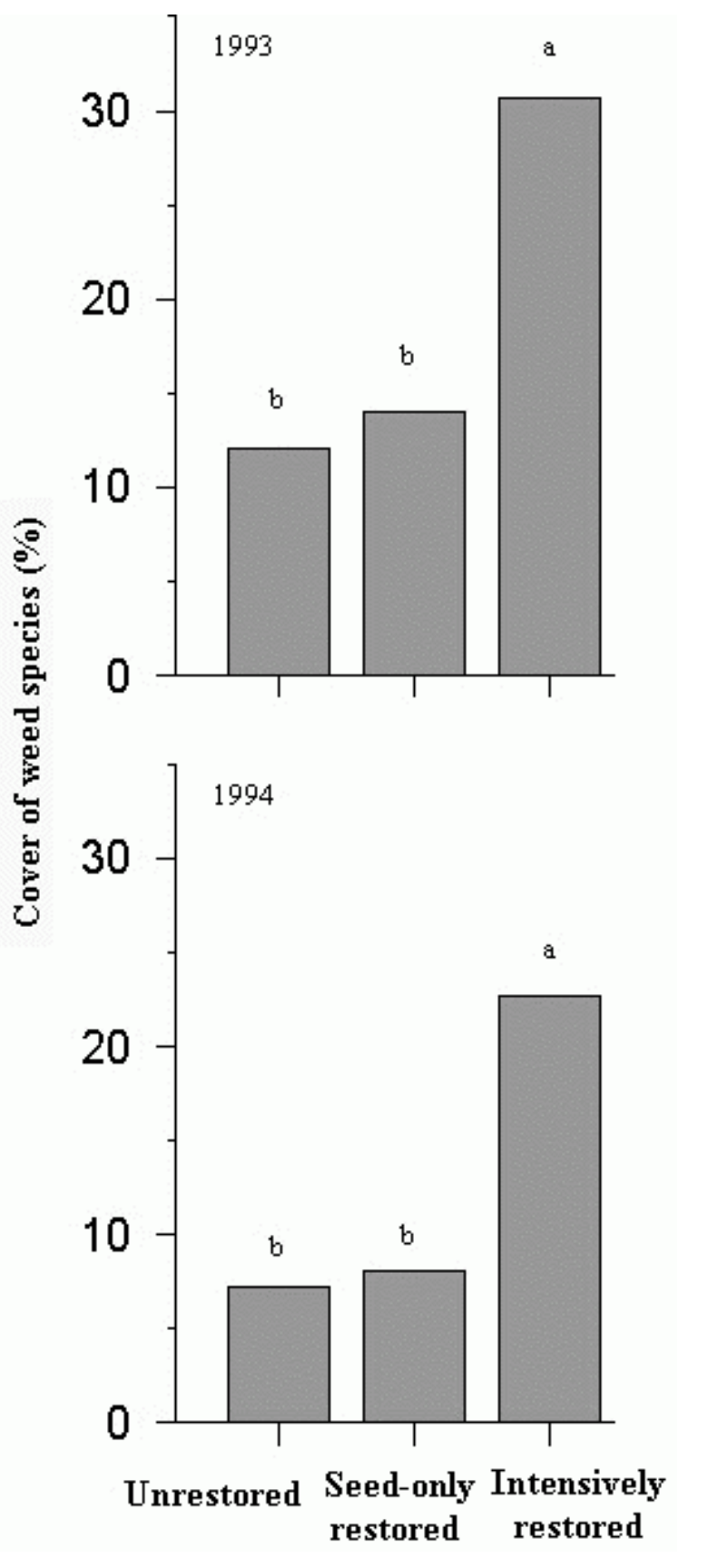


Fig. 4. Biomass of prairie and extant grasses and forbs in biomass-harvest subplots $7 \mathrm{yr}$ after restoration. See Table 2 for details of analyses.

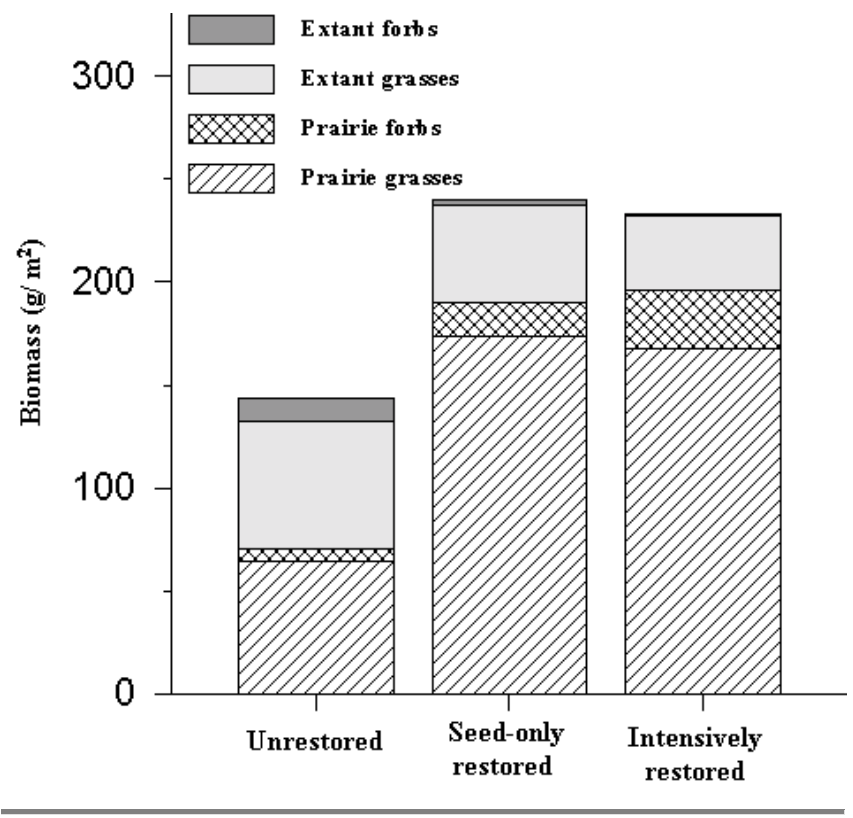

\section{Prairie cover in stem-count subplots}

Cover of prairie species in stem-count subplots increased with both seed-only and intensive restoration (Table 2). Prairie cover was 3\% in unrestored, 55\% in seed-only restored, and $72 \%$ in intensively restored subplots. Prairie cover was significantly higher in intensively restored than in seed-only restored plots.

\section{Resource availability}

Of the resources measured, only light was influenced by restoration (Table 2). Because repeated measures ANOVA revealed no significant effects of sampling date, we present averages of light penetration on the June and September sampling dates (Fig. 5). Light penetration to the soil surface was significantly lower in both seed-only and intensively restored plots than in unrestored plots. Available $\mathrm{NO}_{3}-\mathrm{N}$ ranged from 0.09 to $0.46 \mathrm{mg} / \mathrm{kg}$, and available $\mathrm{NH}_{4}-\mathrm{N}$ ranged from 0.42 to $1.17 \mathrm{mg} / \mathrm{kg}$. Water content ranged from 0.026 to 0.048 $\mathrm{g} / \mathrm{g}$ of soil.

\section{DISCUSSION}

Seven years after prairie restoration, intensive restoration resulted in large reductions in weed biomass (Fig. 1) and stem number (Fig. 2) compared to unrestored plots. Two lines of evidence suggest that the establishment of prairie species, rather than the herbicides and tillage used during intensive prairie restoration, account for the observed decreases in weed success. Seed-only restoration, which did not involve herbicides and tillage, also reduced weed stem number. Furthermore, although intensive restoration decreased weed mass and stem number over the long term, it increased weed cover in the years immediately following tillage and herbicide application (Fig. 3). These results support the suggestion that prairie restoration may serve as a means of weed control (Cramer 1991).

Fig. 5. Percent light penetration, averaged between June and September sampling dates. Bars represent restoration treatment means. Bars with different letters are significantly different based on Tukey HSD tests $(P<0.05)$.

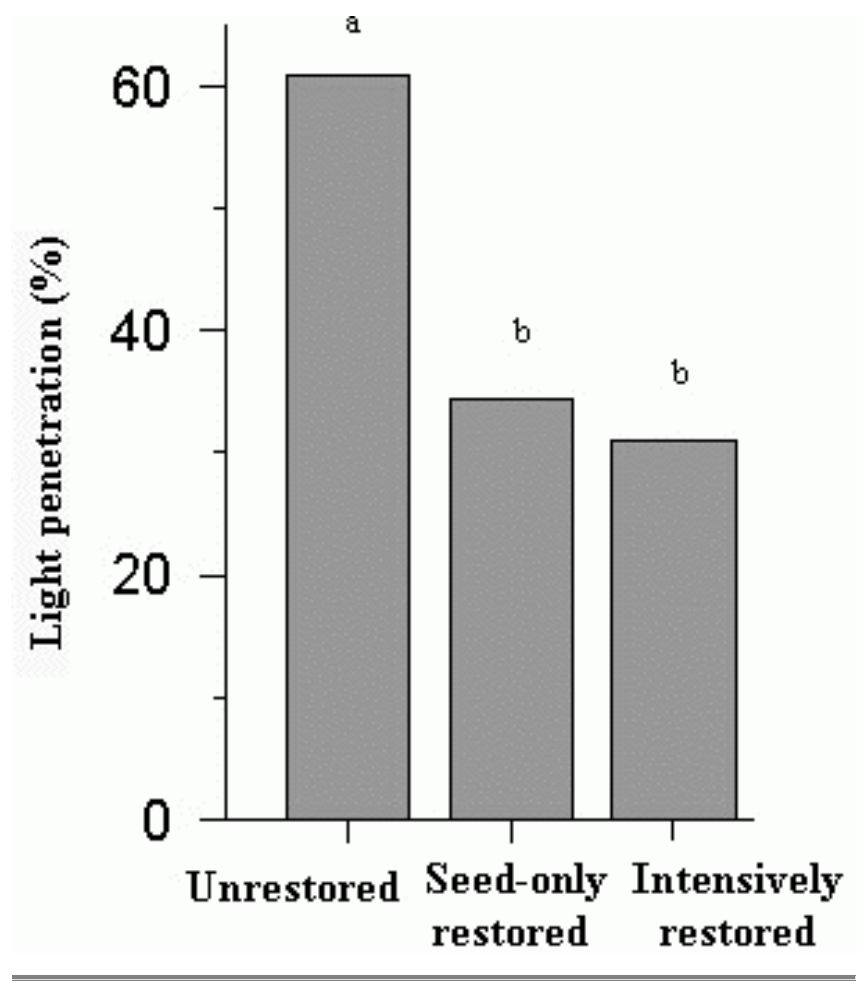

The potential of prairie restoration for controlling weeds is also suggested by the consistency of response among weed species and the variety of species controlled. Intensive prairie restoration reduced the stem numbers of four individual weed species (Table 3). Furthermore, no weed species increased in stem number with restoration. The weeds controlled included one annual dicot, one perennial dicot, one annual monocot, and one perennial monocot. These patterns suggest that prairie restoration may control a 
broad array of weed species. It should be noted, however, that our data are from a single site at a single point in time. Although patterns of weed invasion appeared to be qualitatively similar in 1999 (D. M. Blumenthal, personal observation), we cannot rule out the possibility that the observed patterns are transient or site-specific.

Seeding prairie species without site preparation resulted in a high cover of prairie species, particularly prairie grasses (Fig. 4), and reduced weed stem numbers (Fig. 2). These results suggest that in some instances it may be possible to restore prairie and control weeds simply by adding seed of prairie species. However, the relatively infertile, dry soils of the study site may have contributed to the success of prairie species without site preparation. In more fertile, moist sites, intensive site preparation, perhaps in conjunction with reductions in fertility, may be necessary for prairie species to compete effectively with weed species (Morgan 1997).

We found that restoration greatly increased total aboveground biomass (Fig. 4) and greatly reduced light availability (Fig. 5). These results are consistent with the hypothesis that the diversity (Table 2) and/or species composition (Fig. 4) of restored prairie would diminish weed invasion by increasing the strength of competitive effects and associated reductions in available resources (Vitousek and Walker 1987, Case 1990, Jacobs and Sheley 1999, Davis et al. 2000, Naeem et al. 2000). Nevertheless, our results do not rule out other mechanisms known to influence plant invasions, including establishment limitation (Harper 1965, Crawley 1987), phenology (Crawley 1989), and the presence of mutualists or antagonists (Crawley 1987).

\section{SPECULATION}

The success of restoration in controlling weeds in this experiment suggests that weed control costs might be substantially reduced by using prairie restoration to control weeds. In 1994, the estimated cost of weed control in U.S. highway rights of way alone was U.S.\$276 million (Westbrooks 1998). Considerably more was spent on weed control in other nonagricultural areas. The low management requirements of restored prairie suggest that, if it can serve as a reliable weed control method, weed control costs in noncropland might be greatly reduced. In this experiment, all plots were burned twice in the $7 \mathrm{yr}$ between restoration and weed measurement, in accord with the suggestion that burning once every $3-4 \mathrm{yr}$ is sufficient to favor prairie species over weed species (Pauly 1997). Using prairie restoration for weed control also has the potential to reduce herbicide use, increase the diversity of native plant and animal species (Kline 1997), increase water quality (Jastrow 1987, Schilling and Thompson 2000), and increase carbon storage (Potter et al. 1999, Knops and Tilman 2000). Together, these benefits may substantially offset the short-term costs of prairie restoration, providing a strong incentive for large-scale prairie restoration (Edwards and Abivardi 1997).

Insofar as reductions in resource availability with restoration cause observed reductions in weed success, several hypotheses might be drawn regarding the degree to which our results may be extrapolated to other species and environments. First of all, restored prairie would be more likely to exclude weeds adapted to high-resource agricultural ecosystems than lowresource natural ecosystems. Second, increases in resource availability, whether through resource addition or decreases in resource uptake (Davis et al. 2000), would be expected to increase the invasibility of prairie by weeds. Where the environment has been substantially altered, it may be necessary to restore abiotic factors, e.g. edaphic conditions, hydrology, or disturbance regimes, as well as biotic factors to achieve weed control (Berger 1993). Finally, because other diverse, late-successional native plant communities may also reduce resource availability, restoration of these plant communities might also be expected to have weed control value. Direct tests of the above hypotheses, together with studies of the mechanisms that control the invasibility of restored plant communities, would greatly increase our ability to determine when and where restoration can be used to control weeds.

Responses to this article can be read online at: http://www.consecol.org/vol7/iss1/art6/responses/index.html

\section{Acknowledgments:}

We are grateful to R. Becker, D. Bosanko, C. Brown, S. Huerd, D. Krueger, L. Perry, Z. Pollenski, K. Schmidt, M. Russell, D. Tilman, and two anonymous reviewers for assistance with the design, implementation, and presentation of this study. Partial funding was provided by a Natural Systems Agriculture Fellowship from The Land Institute. 


\section{LITERATURE CITED}

Baker, H. G. 1965. Characteristics and modes of origin of weeds. Pages 147-172 in H. G. Baker and G. L. Stebbins, editors. The genetics of colonizing species. Academic Press, New York, New York, USA.

Bazzaz, F. A. 1996. Plants in changing environments: linking physiological, population, and community ecology. Cambridge University Press, Cambridge, UK.

Berger, J. J. 1993. Ecological restoration and nonindigenous plant species: a review. Restoration Ecology 1:74-82.

Bugg, R. L., C. S. Brown, and J. H. Anderson. 1997. Restoring native perennial grasses to rural roadsides in the Sacramento Valley of California: establishment and evaluation. Restoration Ecology 5:214-228.

Case, T. J. 1990. Invasion resistance arises in strongly interacting species-rich model competition communities. Proceedings of the National Academy of Science 87:96109614.

Chapin, F. S. 1980. The mineral nutrition of wild plants. Annual Review of Ecology and Systematics 11:233-260.

Cook, R. D., and S. Weisberg. 1999. Applied regression including computing and graphics. John Wiley, New York, New York, USA.

Cramer, C. 1991. Tougher than weeds-native prairie plants, better management trim roadside spraying $90 \%$. The New Farm 13:37-39.

Crawley, M. J. 1987. What makes a community invasible? Pages 429-454 in M. J. Crawley, P. J. Edwards, and A. J. Gray, editors. Colonization, succession and stability. Blackwell Scientific, Oxford, UK.

Crawley, M. J. 1989. Chance and timing in biological invasions. Pages 407-424 in J. A. Drake, H. A. Mooney, F. di Castri, R. H. Groves, F. J. Kruger, M. Rejmanek, and M. Williamson, editors. Biological invasions: a global perspective. John Wiley, Chichester, UK.

Davis, M. A., J. P. Grime, and K. Thompson. 2000. Fluctuating resources in plant communities: a general theory of invasibility. Journal of Ecology 88:528-534.

Durgan, B. R. 1998. Identification of the primary noxious weeds of Minnesota. University of Minnesota Extension Service, St. Paul, Minnesota, USA.

D'Antonio, C., and L. A. Meyerson. 2002. Exotic plant species as problems and solutions in ecological restoration: a synthesis. Restoration Ecology 10:703-713.
Edwards, P. J., and C. Abivardi. 1997. Ecological engineering and sustainable development. Pages 325-352 in K. M. Urbanska, N. R. Webb, and P. J. Edwards, editors. Restoration ecology and sustainable development. Cambridge University Press, Cambridge, UK.

Gleason, H. A., and A. Cronquist. 1991. Manual of vascular plants of northeastern United States and adjacent Canada. New York Botanical Garden, Bronx, New York, USA.

Grigal, D. F., L. M. Chamberlain, H. R. Finney, D. V. Wroblewski, and E. R. Gross. 1974. Soils of the Cedar Creek Natural History Area. University of Minnesota Agricultural Experiment Station, St. Paul, Minnesota, USA.

Harper, J. L. 1965. Establishment, aggression, and cohabitation in weedy species. Pages 243-268 in H. G. Baker and G. L. Stebbins, editors. The genetics of colonizing species: proceedings of the first international union of biological sciences symposia on general biology. Academic Press, New York, New York, USA.

Jacobs, J. S., and R. L. Sheley. 1999. Competition and niche partitioning among Pseudoroegneria spicata, Hedysarum boreale, and Centaurea maculosa. Great Basin Naturalist 59:175-181.

Jastrow, J. D. 1987. Changes in soil aggregation associated with tallgrass prairie restoration. American Journal of Botany 74:1656-1664.

Kline, V. M. 1997. Orchards of oak and a sea of grass. Pages 3-21 in S. Packard and C. F. Mutel, editors. Tallgrass restoration handbook. Island Press, Washington, D.C., USA.

Knops, J. M. H., and D. Tilman. 2000. Dynamics of soil nitrogen and carbon accumulation for 61 years after agricultural abandonment. Ecology 81:88-98.

Morgan, J. P. 1997. Plowing and seeding. Pages 193-215 in S. Packard and C. F. Mutel, editors. Tallgrass restoration handbook. Island Press, Washington, D.C., USA.

Naeem, S., J. M. H. Knops, D. Tilman, K. M. Howe, T. Kennedy, and S. Gale. 2000. Plant diversity increases resistance to invasion in the absence of covarying extrinsic factors. Oikos 91:97-108.

Pauly, W. R. 1997. Conducting burns. Pages 3-21 in S. Packard and C. F. Mutel, editors. Tallgrass restoration handbook. Island Press, Washington, D.C., USA.

Potter, K. N., H. A. Torbert, H. B. Johnson, and C. R. Tischler. 1999. Carbon storage after long-term grass establishment on degraded soils. Soil Science 164:718-725.

Rejmanek, M. 1989. What attributes make some plant species more invasive? Pages 369-388 in J. A. Drake, H. A. Mooney, F. di Castri, R. H. Groves, F. J. Kruger, M. Rejmanek, and M. Williamson, editors. Biological 
invasions: a global perspective. John Wiley, Chichester, UK.

SAS Institute. 1990. SAS/STAT® users guide. Fourth edition. SAS Institute, Cary, North Carolina, USA.

Schilling, K. E., and C. A. Thompson. 2000. Walnut Creek Watershed Monitoring Project Iowa: monitoring water quality in response to prairie restoration. Journal of the American Water Resources Association 36:1101-1114.

Stubbendieck, J., G. Y. Friisoe, and M. R. Bolick. 1994. Weeds of Nebraska and the Great Plains. Nebraska Department of Agriculture, Lincoln, Nebraska, USA.

Svenson, E. L. 1995. Response of prairie species and oldfield vegetation in an experimental restoration from seed. Thesis, University of Minnesota, St. Paul, Minnesota, USA.

Tilman, D. 1988. Plant strategies and the dynamics and structure of plant communities. Princeton University Press, Princeton, New Jersey, USA.

Tilman, D. 1997. Community invasibility, recruitment limitation, and grassland biodiversity. Ecology 78:81-92.

USDA. 1971. Common weeds of the United States. Dover Publications, New York, New York, USA.

Vitousek, P. M., and L. R. Walker. 1987. Colonization, succession and resource availability: ecosystem-level interactions. Pages 207-222 in M. J. Crawley, P. J. Edwards, and A. J. Gray, editors. Colonization, succession and stability. Blackwell Scientific, Oxford, UK.

Westbrooks, R. 1998. Invasive plants, changing the landscape of America: fact book. Federal Interagency Committee for the Management of Noxious and Exotic Weeds, Washington, D.C., USA. 